\title{
Evaluation of Substitution of Noug Seed Cake with Pigeon Pea Dried Leaves as a Supplement Feed in Fattening Oxen Based on Teff Straw Basal Diet at Haik Agricultural Research Sub-Center, Ethiopia
}

\author{
Abito Asres* Solomon Tiruneh Negus Belayneh \\ Sirinka Agricultural Research Center, P.O.Box, 74, Sirinka, Ethiopia
}

\begin{abstract}
The experiment was conducted to evaluate substitution of noug seed cake with dried pigeon pea leaves on feed intake and weight gain of local old oxen. A total of 25 local old oxen (Bos indicus) with 7-8 years old and an initial mean body weight of $300.2 \pm 19.25 \mathrm{~kg}$ (mean $\pm \mathrm{SD}$ ) were used for the study. The experiment was carried out for 105 days including 15 days of acclimatization period. The design employed for this experiment was randomized complete block design with five replications. The dietary treatments were T1= Teff straw ad libtum + Wheat bran + Pigeon pea $(25 \%)+$ Noug seed cake $(75 \%) ; \mathrm{T} 2=$ Teff straw ad libtum + Wheat bran + Pigeon pea $(50 \%)+$ Noug seed cake (50\%); T3=Teff straw ad libtum + Wheat bran + Pigeon pea (75\%)+ Noug seed cake(25\%); T4= Teff straw ad libtum + Wheat bran +Pigeon pea (100\%); T5= Teff straw ad libtum +Wheat bran + Noug seed cake $(100 \%)$. The result showed that crude protein content of Pigeon pea dried leaves $(24.47 \%)$, noug seed cake $(31.92 \%)$ and wheat bran $(15.98 \%)$ can satisfy ruminant production requirement. Total dry matter, teff straw and nutrient intake were statically highly significant $(\mathrm{P}<0.01, \mathrm{P}<0.001, \mathrm{P}<0.001)$ respectively between treatment groups but supplement intake was not statically significant $(\mathrm{P}>0.05)$ among treatment groups. The average total DM intakes of all treatment groups were ranged from 7.29 to $8.09 \mathrm{~kg} / \mathrm{d} /$ head. There were no significant differences $(\mathrm{P}>0.05)$ in initial body weight gain, final body weight gain, total body weight gain and average daily body weight gain among different combinations of treatment groups. The average daily weight gain (675.56 g), gross benefit (2159.96 ETB) and marginal revenue 1.11ETB of treatment 2 was higher than other treatment groups. Therefore, it is recommended that fattening of old local oxen using supplement combination levels of teff straw + wheat bran + $50 \%$ pigeon pea $+50 \%$ noug cake resulted better body weight gain and good benefit.
\end{abstract}

Keywords: Body weight gain; Fattening; Noug seed cake; Old oxen; Pigeon pea

DOI: $10.7176 / \mathrm{JBAH} / 11-2-01$

Publication date: January $31^{\text {st }} 2021$

\section{Introduction}

Cattle fattening activity is one of the potential sources for employment opportunity and to increase the volume and quality of meat produced and to alleviate poverty in Ethiopia (Kerstin et al., 2011). Cattle fattening has gained prominence as an important business project of the livestock industry in Ethiopia to make use of cheap, plentiful farm by-products (Habtamu et al., 2008). Moreover, fattening offers opportunity to exploit the vast cattle and meet export market in the region as well as Ethiopia's domestic market (Habtamu, 2012). The fattening activity can be undertaken at any level of livestock value chain ranging from small holder farmers rearing livestock for multiple functions (Sarma and Ahmed, 2011), and small scale commercial fattening to large scale commercial fattening (Tsegay and Mengistu, 2013). Beef cattle fattening is a common practice in Ethiopia and special attention was given by the government to boost red meat supply through cattle fattening (Agmas and Adugna, 2018).

In Ethiopia, productivity of beef is very low which might be related to feed shortage, diseases and parasites, drought, shortage of grazing land, market access, veterinary services, extension services and use low performance local breed (Matawork, 2017). Among the major constraints, shortage and low quality feed could be considered as an important factor. Feed is a major factor that affects livestock productivity and contributes to nearly $65 \%$ of the phenotypic expressions of the animals' performance and the same percent of running costs in pen feeding (Yeshitila et al., 2009). Therefore, to mitigate problems related to shortage of feed particularly protein deficit in ruminant animals, use of locally available fodder species that can replace purchased concentrates. Among candidate fodder species is pigeon pea is the one.

Pigeon pea (Cajanus cajan) is a plant that is cultivated for human food and animal feed. It exists as a wide range of cultivars, and their flexibility for use in animal rearing systems have made pigeon pea popular, especially for small-scale farmers. Pigeon pea is grown widely in India and in parts of Africa and Central America. The main producers of pigeon pea in the world are India, Uganda, Tanzania, Kenya, Malawi, Ethiopia, Mozambique, the Dominican Republic, Puerto Rico, the West Indies in the Caribbean and Latin America region, Indonesia and the Philippines and Australia (ABD et al., 2018). Pigeon pea is relatively resistant to drought, improves soil fertility and prevents soil erosion on steep land. It's in Eastern Africa countries (Damaris, 2007).

Pigeon pea (Cajanus cajan) has relatively good crude protein (CP) content 16.3-27 \% (Ahmed and Nour, 
1997). The dry matter and CP value of pigeon pea leaf-twig mixed were $904 \mathrm{~g} / \mathrm{kg}$ and $236 \mathrm{~g} / \mathrm{kg}$, respectively (Shumuye et al., 2016). Pigeon pea has a potential to produce high biomass ranging from 40.0 to $57.6 \mathrm{t}$ DM ha-1. Cattle feeding based on pigeon pea pasture have gained in weight from 0.7 to $1.25 \mathrm{~kg} / \mathrm{head} /$ day at a carrying capacity of 1 to 3.75 beasts/ha, and live weight gains of 200 to $500 \mathrm{~kg} / \mathrm{ha} / \mathrm{annum}$ have been recorded(Akinola et al., 1975). Grain yield vary from 1500 to $3000 \mathrm{~kg} / \mathrm{ha} / \mathrm{yr}$ of shelled grain (Alemayehu Menigstu et al., 2017).

The most cattle fattening practices in Ethiopia use diverse feed resources, including concentrates, it seems costly venture and requires alternative feed supplements that can be locally available. Hence, in the past, efforts have been made to identify adaptable and high yielding forage crops for the mid and low land areas of Eastern Amhara. Among these, Pigeon pea has been founded to be promising and recommended for the area. According to the information obtained from the farmers, they utilize Pigeon pea as animal fattening on some extent but farmers lack knowledge on how to use the fodder particularly the stage of harvest and related management. This indicated that the fodder produced from pigeon pea is not efficiently utilized. On the other hand, it is important to efficiently utilize the available fodder to replace purchased concentrates so as to make fattening a profitable business. Hence, this experiment was conducted to evaluate the substitution of noug seed cake with dried pigeon pea leaves in a concentration mixture on feed intake and weight gain of local old oxen.

\section{Materials and Methods}

\subsection{Description of the Study Area}

The experiment was conducted at Haik Agricultural Research Sub- Center, South Wollo Zone of Amhara region. The area is situated at $11^{0} 21^{\prime} 00^{\prime \prime} \mathrm{N}$ latitude and $39^{0} 38^{\prime} 00^{\prime \prime} \mathrm{E}$ longitude located at about $435 \mathrm{kms}$ North of Addis Ababa Capital City of Ethiopia. It lies within an altitude of 1680 meter above sea level. The area receives an average annual rain fall of $1204.6 \mathrm{~mm}$ and a mean range temperature of $11.2-25.6^{\circ} \mathrm{c}$.

\subsection{Experimental Animal's Management and Treatments}

The feeding trial was carried out for 105 days including 15 days of acclimatization period, from April 13/2018 to July 26/2018. A total of 25 local old oxen (Bos indicus) with the approximate age of six to seven years old (based on dentition) and mean initial live weight of $300.2 \pm 19.25 \mathrm{~kg}$ (mean $\pm \mathrm{SD}$ ) were borrowed from the surrounding farmers. The borrower farmers were benefited on they had got knowledge and extra income. The animals were quarantine for twenty one days and during this period they were vaccinated for common disease (Pasteurellosis and Black leg) in the area and treated for internal and external parasites. The experimental design used in the study was randomized complete block design (RCBD) with five replications.

The experimental animals were stratified based on their initial body weight and randomly assigned in to 5 treatment groups. The experimental feeds offered for oxen were:

$\mathrm{T} 1=$ Teff straw ad libtum + Wheat bran + Pigeon pea dried leaves $(25 \%)+$ Noug seed cake $(75 \%)$

$\mathrm{T} 2=$ Teff straw ad libtum + Wheat bran + Pigeon pea dried leaves $(50 \%)+$ Noug seed cake $(50 \%)$

$\mathrm{T} 3=$ Teff straw ad libtum + Wheat bran + Pigeon pea dried leaves $(75 \%)+$ Noug seed cake $(25 \%)$

$\mathrm{T} 4=$ Teff straw ad libtum + Wheat bran + Pigeon pea dried leaves $(100 \%)$

T5= Teff straw ad libtum + Wheat bran + Noug seed cake $(100 \%)$

\subsection{Feed Preparation and Feeding}

Pigeon pea was planted the rainy season in an area where experiment was done and used as hay for study on its optimum stage. It was harvested at $1 \mathrm{~m}$ height. After air dried the leaf part was lopped and packed in the sack for the later use. Wheat bran and Noug seed cake for this study were purchased from market. The proportion of wheat bran, noug seed cake and pigeon pea and the amount provide to the animals was calculated on dry matter basis. All experimental animals were allowed to feed Teff straw on ad-libtum. Supplement feeds were provided two times a day at morning 8:00 AM and afternoon 4:00 PM. The experimental animals were drunken water twice a day based on farmers practice and simple observation of oxen interested to drunken water.

\subsection{Data Collection and Analysis}

Initial body weight was measured at the beginning of the experiment and overnight fasted body weight was recorded fortnightly then after. Total weight gain was calculated by subtracting final body weight from initial body weight and average daily weight gains by dividing total body weight gains by experimental periods. Daily feed offer and left over was measured and recorded. The initial costs of the animals were recorded and at the end of the experiment the selling price was estimated using three local live animal dealers. The data was analyzed using Genstat software ( $18^{\text {th }}$ edition) and a significant mean difference was separated using Duncan's multiple range test at $\mathrm{P}<0.05$. 


\section{Results and Discussion}

3.1. Chemical Composition of Experimental Feeds

The chemical composition of experimental feeds are shown in table 1.The crude protein content of Teff straw $(5.02 \%)$ was below the maintenance requirement (7\%) of adult ruminants. The straw contains high NDF (84.2\%), ADF (61.36\%) and ADL (30.71\%) which affects DM intake and digestibility. The crude protein content of Pigeon pea dried leaves $(24.47 \%)$, Noug seed cake $(31.92 \%)$ and wheat bran $(15.98 \%)$ can satisfy adult cattle production requirement. The NDF and ADL content of pigeon pea dried leaves, noug seed cake and wheat bran were $(53.33 \%$, $29.29 \%),(64.44 \%, 15.15 \%)$ and $(30.14 \%, 23.64 \%)$, respectively.

The result indicated that Teff straw based diet required supplemented feed like browse trees and agro industrial by products to improve the performance of mature oxen. The CP and NDF content of Noug seed cake was higher compared with Pigeon pea dried leaves. This shows that Pigeon pea had low fiber content than Noug seed cake and can improve intake and digestibility. The CP content of Pigeon pea in the current study was higher as compared with reports of $17.01 \%$, Solomon et al. (2016), $23 \%$ reported by, Ajebu et al. (2013).

Table1. Chemical composition of experimental feeds

\begin{tabular}{lllllll}
\hline Ingredients & \multicolumn{7}{c}{ Parameters } \\
\cline { 2 - 6 } Teff straw & DM\% & Ash $\%$ & CP\% & NDF\% & ADF\% & ADL\% \\
Pigeon pea & 88 & 9.09 & 5.02 & 84.20 & 61.36 & 30.71 \\
Noug seed cake & 89 & 10.11 & 24.47 & 53.33 & 29.29 & 24.4 \\
Wheat bran & 89 & 10.11 & 31.92 & 64.44 & 15.15 & 6.6 \\
\hline $\begin{array}{l}\text { DM =dry matter; } \\
\text { detergent lignin }\end{array}$ & 89 & 12.36 & 15.98 & 30.14 & 23.64 & 13.04 \\
\hline crude protein $;$ & $N D F=$ neutral detergent fiber; ADF =acid detergent fiber; ADL $=$ acid
\end{tabular}

\subsection{Feed Intake}

The total feed and nutrient intake showed in table 2. Total dry matter, basal diet (Teff straw) and nutrient intake had highly significance difference $(\mathrm{P}<0.01, \mathrm{P}<0.001$ and $\mathrm{P}<0.001)$ respectively among treatments but supplement intake had not significance difference $(\mathrm{P}>0.05)$ among treatments. The total dry matter intake ranged from 7.29 to $8.09 \mathrm{~kg} / \mathrm{d} / \mathrm{head}$. This report was highly disagreed with the work of Tesfaye et al. (2005) in who reported supplementation of Oxen with Leucaena pallida had total dry matter intake of $2.4 \mathrm{~kg} / \mathrm{d} / \mathrm{head}$. Total dry matter intake of treatment 1, 2, 4 and 5 were higher as compared to treatment 3 . In all levels, supplementation of pigeon pea was not significantly different among treatment in the intakes of crude protein. The combination of ingredients teff straw + wheat bran $+50 \%$ pigeon pea $+50 \%$ noug cake was given best dry matter intake $8.09 \mathrm{~kg} / \mathrm{d} / \mathrm{head}$ than other combinations.

Table2. Feed and nutrient intake of oxen

\begin{tabular}{llllllllll}
\hline Parameters & \multicolumn{9}{c}{ Treatments } \\
\hline DMI(kg/d/head) & T1 & T2 & T3 & T4 & T5 & G mean & SEM & CV & SL \\
Teff straw & & & & & & & & & \\
Supplement & $4.47^{\mathrm{a}}$ & $4.62^{\mathrm{a}}$ & $4.00^{\mathrm{b}}$ & $4.65^{\mathrm{a}}$ & $4.54^{\mathrm{a}}$ & 4.46 & 0.06 & 3.8 & $* * *$ \\
$\quad$ Total & 3.55 & 3.47 & 3.29 & 3.43 & 3.26 & 3.4 & 0.05 & 6.3 & Ns \\
Nutrient intake(kg/d/head) & $8.02^{\mathrm{a}}$ & $8.09^{\mathrm{a}}$ & $7.29^{\mathrm{b}}$ & $8.08^{\mathrm{a}}$ & $7.80^{\mathrm{a}}$ & 7.86 & 0.08 & 3.8 & $* *$ \\
CPI & & & & & & & & & \\
NDFI & $0.99^{\mathrm{a}}$ & $0.98^{\mathrm{a}}$ & $1.02^{\mathrm{a}}$ & $0.98^{\mathrm{a}}$ & $0.79^{\mathrm{b}}$ & 0.95 & 0.02 & 5 & $* * *$ \\
ADFI & $3.87^{\mathrm{d}}$ & $4.35^{\mathrm{bc}}$ & $4.50^{\mathrm{b}}$ & $4.95^{\mathrm{a}}$ & $4.12^{\mathrm{c}}$ & 4.36 & 0.08 & 4.3 & $* * *$ \\
ADLI & $2.44^{\mathrm{c}}$ & $2.89^{\mathrm{b}}$ & $3.03^{\mathrm{b}}$ & $3.50^{\mathrm{a}}$ & $2.83^{\mathrm{b}}$ & 2.94 & 0.08 & 5.2 & $* * *$ \\
\hline
\end{tabular}

$T=$ treatment; $D M I=$ dry matter intake; $d=$ day; $C P I=$ crud protein intake; $N D F I=$ neutral detergent fiber intake; $A D F I=$ acid detergent fiber intake; $A D L I=$ acid detergent lignin intake; $G=$ grand; $C V=$ coefficient of variance; $S E M=$ standard error of mean; $S L=$ significance level; $n s=$ non significant; $* *=$ significant $P<0.01$; $* * *=$ Significant $P<0.001$

\subsection{Live Weight Gain}

Initial and final body weight changes, average daily weight gain and feed conversion efficiency Pigeon pea and concentrate mixture supplementation on Teff straw based fattening of oxen is presented in table 3 . The results showed that there were no significant differences $(\mathrm{P}>0.05)$ in initial body weight gain, final body weight gain, total body weight gain and average daily body weight gain among the different combinations of treatment groups. It is unlikely that animals fed different level of Pigeon pea dried leaves performed similarly. This effect might be because of the nutritional value of the pigeon pea dried leaves were better than other supplements. The similarity in body weight gain among treatments reflects that the supplements are comparable in their nutrient supply. Sole 
noug seed cake supplementation (T5) resulted in a gain of $588.89 \mathrm{~g} /$ day which is almost statistically similar to those supplemented with sole pigeon pea leaves (T4) (655.56 g/day) which indicates the significance of pigeon pea leaves as a Crud protein supplement has a potential substitute noug seed cake supplementation fully to fatten local oxen in the study area.

The numerical value of average daily weight gain of treatment two was the highest (675.56 g) as compared with T1,T3,T4 and T5; which had average daily weight gain values of $662.22 \mathrm{~g}, 575.5 \mathrm{~g}, 655.56 \mathrm{~g}$ and $588.89 \mathrm{~g}$, respectively. The average daily body weight gain of this study was significantly higher than reported by Wondimagegne and Mesfin (2012) who supplemented oxen with different levels of Leucaena pallida was 355.6 $\mathrm{g} /$ head/day and reported on Tesfaye et al. (2005) $400 \mathrm{~g} / \mathrm{head} / \mathrm{day}$.

Table3. Body weight change of oxen supplemented with different feeding level of pigeon pea and noug seed cake

\begin{tabular}{llllllllll}
\hline Bodyweight change & \multicolumn{10}{c}{ Treatments } \\
\cline { 2 - 11 } & T1 & T2 & T3 & T4 & T5 & $\begin{array}{l}\text { Over all } \\
\text { mean }\end{array}$ & SEM & CV & SL \\
Initial BW(kg) & 304 & 303.6 & 286.6 & 306.2 & 300.8 & 300.2 & 3.85 & 6.5 & Ns \\
Final BW(kg) & 363.6 & 364.4 & 338.4 & 365.2 & 353.8 & 357.1 & 5.09 & 7.1 & Ns \\
Total BW gain(kg) & 59.6 & 60.8 & 51.8 & 59 & 53 & 56.8 & 2.55 & 23.5 & Ns \\
ADWG(g/d/head) & 662.22 & 675.56 & 575.56 & 655.56 & 588.89 & 631.56 & 0.03 & 23.5 & Ns \\
FCE & 0.082 & 0.083 & 0.079 & 0.081 & 0.076 & 0.08 & 0.003 & 21.5 & Ns \\
\hline
\end{tabular}

$T=$ treatment; $C V=$ coefficient of variance; $S L=$ significance level; $S E M=$ standard errors of mean; $B W=$ body weight; $A D W G=$ average daily weight gain; $F C E=$ feed conversion efficiency; $N$ s $=$ non significance

\subsection{Partial Budget Analysis of Fattened Oxen}

The partial budget analysis result of the current fattening experiment is shown in table 4. The gross benefit of T2 (2159.96 ETB) was higher than others T1 (1323.18 ETB), T3 (1247.15 ETB), T4 (1666.39 ETB), T5 (2081.04 ETB).The marginal revenue of T2 was also higher 1.11ETB than T1, T3, T4 and T5 with the estimated values; 1.06 ETB, 1.06 ETB, 1.08 ETB and 1.10 ETB, respectively. The experiment indicated that fattening of an ox with combined supplementation of $50 \%$ Pigeon pea dried leaf and 50\% noug seed cake earned 2159.96 ETB which was the best cost benefit or economically feasible feeding combination as to others supplementation levels. The marginal revenue of $\mathrm{T} 2$ also indicated that one ETB investment on input for fattening of ox provided gross profit of 1.11 ETB.

Table4. Partial budget analysis

\begin{tabular}{llllll}
\hline Items & \multicolumn{5}{c}{ Treatments } \\
\cline { 2 - 6 } & T1 & T2 & T3 & T4 & T5 \\
Gross benefits(ETB) & 22200 & 22400 & 20600 & 22200 & 22600 \\
Total cost that vary(ETB) & 20876.82 & 20240.04 & 19352.85 & 20533.61 & 20518.96 \\
Total feed cost(90 days)(ETB) & 4554.58 & 4297.8 & 3930.61 & 4191.37 & 4636.72 \\
Veterinary service cost (ETB) & 157.92 & 157.92 & 157.92 & 157.92 & 157.92 \\
labor cost (ETB) & 764.32 & 764.32 & 764.32 & 764.32 & 764.32 \\
Initial ox price (ETB) & 15400 & 15020 & 14500 & 15420 & 14960 \\
Net benefits(ETB) & 1323.18 & 2159.96 & 1247.15 & 1666.39 & 2081.04 \\
Marginal revenue(ETB) & 1.06 & 1.11 & 1.06 & 1.08 & 1.10 \\
\hline
\end{tabular}

$T=$ treatment; $E T B=$ Ethiopian birr

\section{Conclusion and Recommendation}

The result of this experiment showed that Pigeon pea dried leaves can be used as the best supplementation of crop residues. Supplementation of Pigeon pea dried leaves improves the dry matter intake and performance of oxen in terms of body weight gain. In all treatment combinations, Pigeon pea dried leaves was given the same daily weight gain. The result indicated that feeding Pigeon pea dried leaves as a supplement for old oxen fully substituted noug seed cake supplementation. Of the treatment combinations fattening of oxen with supplementation of $50 \%$ Pigeon pea dried leaves and 50\% noug seed cake was profitable than other treatment combination levels. Supplementation of pigeon pea dried leaf feel oneself revenue in ox fattening. Therefore, supplementation of old zebu oxen using feed combination levels of teff straw (ad libtum) + wheat bran $+50 \%$ pigeon pea dried leaf $+50 \%$ noug seed cake gave better fattening performance and profitable business which should be demonstrated for smallholder farmers in the study area and other similar farming systems.

\section{Acknowledgment}

The authors would like to thank SARC and ARARI for financial and over all supports. Our special thanks goes to SARC livestock research directorate researchers and Debre Birhan Agricultural Research Center, livestock 
research directorate for their unreserved research equipment collaboration.

\section{References}

Agmas B. and Adugna M. 2018. Antimicrobial residue occurrence and its public health risk of beef meat in Debre Tabor and Bahir Dar, Northwest Ethiopia.Veterinary World, 11 (7): 902 - 908.

Ahmed M.M.M. and Nour H.S. 1997. Legume hays as a supplement for dairy goats during the dry season. Small Rumin. Res.26: 189-192.

Ajebu Nurfetaa, Asdesach Churfob and Aster Abebea.2013. Substitution of pigeon pea leaves for noug(Guizotia abyssinica) seed cake as a protein supplement to sheep fed low quality tropical grass hay. Ethio. J. Appl. Sci. Techno. Vol. 4(1):1-13.

Akinola JO. and Whiteman PC. 1975. Agronomic studies on pigeon pea (Cajanus cajan L.Millsp.) Field responses to sowing time. Aus. J. Agri. Res.26:43-79.

Alemayehu Mengistu.2002. Forage production in Ethiopia a case study with implications for Livestock production. Ethiopian Society of Animal Production. Addis Ababa, Ethiopia.

Alemayehu Mengistu, Gezahagn Kebede, Getnet Assefa and Fekede Feyissa. 2017. Descriptions and characteristics of cultivated forage crops growing under different Agro Ecological Zones in Ethiopia. Inter J Agri Biosci, 6(5): 238-247.

Damaris AO. 2007. The potential of pigeon pea (Cajanus cajan (L.) Millsp.) In Africa, Natural Resources Forum $31,297-305$

Habtamu A., Mulugeta K., Chala M., Arse G. and Ulfina G. 2008. Proceedings of the 16th Annual Conference of the Ethiopian Society of Animal Production (ESAP) held in Addis Ababa, Ethiopia.

Habtamu Y. 2012. Risk analysis in cattle fattening in North West Ethiopia: Empirical evidence form two liemittobit model. International Journal of Development and Sustainability 1: 240-254.

Kerstin K., Zander A. and Ellengowan D. 2011. Attitudes of Livestock Keepers to Breeding Strategies - Threats and Opportunities for on-farm Conservation of the Borana Cattle Breed. Journal of Agricultural Science: 3.

Matawork Milkias.2017. Beef Cattle Production Systems, Marketing and Constraints in Ethiopia. Journal of Marketing and Consumer Research. ISSN 2422-8451 An International Peer-reviewed Journal Vol.32.

ABD EL-HACK M.E., SWELUM A.A., ABDEL-LATIF M.A., MÁS TORO D. and ARIF M. 2018. Pigeon Pea (Cajanus cajan) as an alternative protein source in broiler feed. World's Poultry Science Journal, Vol. 74.

Sarma PK. and Ahmed JU. 2011. An economic study of small state cattle fattening enterprise of Rajbari district. Journal of Bangladeshian Agriculture Univ 9: 141-146.

Shumuye Belay, Guesh Godifey and Minister Birhanea. 2016. Effect of graded level of pigeon pea (Cajanus cajan) leaves on growth performance of sheep. International Journal of Agricultural Science Research Vol. 5(2), pp. 035-039.

Solomon T., Wondimagegne B., Desalegn A., Asress Z., Niguse B., and Misganawu W.2016. Evaluation of the effect of Pigeon pea dried leave supplementations on feed intake and live weight change on local sheep breed in Eastern Amhara, Ethiopia. Int. J. Adv. Res. Biol. Sci. (2016). 3(12): 81-85.

Tesfaye Lemma, Gebregziabher Gebreyohannes, Chala Merera, Jiregna Desalegn,Girma Aboma and Diriba Geleti. 2005. Comparative Feeding Values of Leucaena Pallida and Noug Cake (G. Abyssinica) for Fattening Horro Steers. Eth. J. Anim. Prod. 5(1) - 2005: 67-76.

Tsegay T. and Mengistu U. 2013. Assessment of commercial feedlot finishing practices at eastern Shoa, Ethiopia. Open Journal of Animal Sciences 4: 273-280.

Wondimagegne Bekele and Mesfin Dejene. 2012. Feed Intake and Body Weight Change of Highland Zebu (Bos Indicus) Oxen Fed Teff (Eragostis Teff) Straw Supplemented with Different Levels of Leucaena Pallida and Wheat Bran. In: Indigenous peoples and Animal Agriculture in Ethiopia: Exploiting the potential and Reducing Limitations. Proceedings of the $19^{\text {th }}$ Annual Conference of the Ethiopian Society of Animal Production (ESAP) held in Addis Ababa, Ethiopia, December 15 to 17.

Yeshitila A.,Tessema Z. and Azage T.2009. Utilization of feeds livestock unit versus dry matter Requirement in Alaba, Southern Ethiopia. Pp.21-32.proceeding of the $16^{\text {th }}$ annual confe rence of the Ethiopian society of animal production (ESAP). Held from 8-10 October 20 08. Addis Ababa, Ethiopia. ESAP, Addis Ababa, Ethiopia.

\section{First Author}

1. Full name: Abito Asres Mengesha

2. Sex: Male

3. Date of birth: October 17, 1990 G.C

4. Place of birth: Gobiye, Ethiopia

5. Nationality: Ethiopian

6. Address: 
Resident town: Woldia

7. Educational background

\begin{tabular}{|l|l|l|l|}
\hline No. & Educational level & Place /University & Year \\
\hline 1 & Elementary (From grade 1-8) & Gobye, Ethiopia & September 1996-June 2004 G.C \\
\hline 2 & High school ( Grade 9 \& 10) & Kobo,Ethiopia & September 2004- June 2006 G.C \\
\hline 3 & Preparatory ( Grade 11 \& 12) & Kobo,Ethiopia & September 2006-June 2008 G.C \\
\hline 4 & BSc degree & Debre Birhan University, Ethiopia & September 2008-June2011G.C \\
\hline 5 & MSc degree & Bahir Dar University, Ethiopia & October 2019- on-going \\
\hline
\end{tabular}

8. Qualification: BSc degree in department of Animal Science and MSc degree in program (specialization) of "Feeds and Animal Nutrition" in on-going.

Second Author

1. Full name: Solomon Tiruneh

2. Sex: Male

4. Place of birth: Dessie, Ethiopia

5. Nationality: Ethiopian

6. Address:

Resident town: Woldia

7. Qualification: BSc degree in department of Animal Science and MSc degree in program (specialization) of "Feeds and Animal Nutrition" at Bahir Dar University, Ethiopia.

Third Author

1. Full name: Negus Belayneh

2. Sex: Male

4. Place of birth: Gojjam, Ethiopia

5. Nationality: Ethiopian

6. Address:

Resident town: Woldia

7. Qualification: DVM degree in department of Veterinary and Animal Health. MSc degree in program (specialization) of Animal Epidemiology at University of Gondar, Ethiopia. 